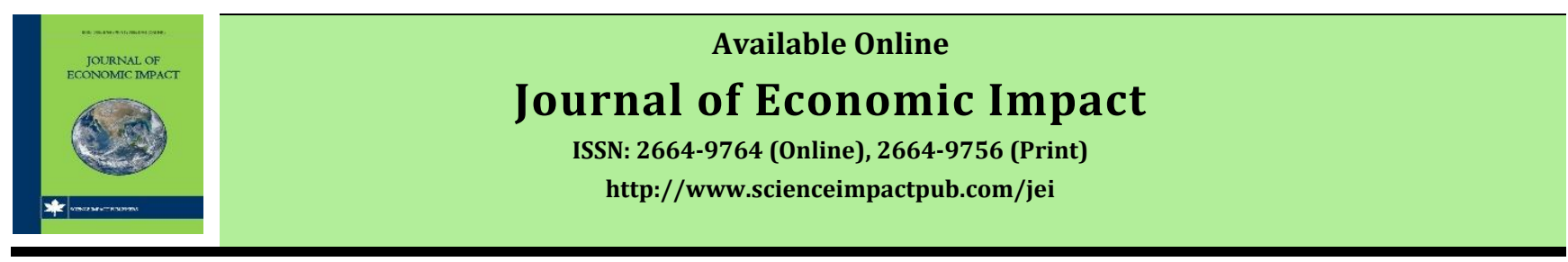

\title{
IMPACT OF CLIMATE CHANGE ON BANANA BASED CROPPING PATTERN IN DISTRICT THATTA, SINDH PROVINCE OF PAKISTAN
}

\section{Ghulam Nabi Dahri a,*, Basit Ali Talpur b, Ghulam Mustafa Nangraj c, Tehmina Mangan a, Muhammad Hassan Channa a , Imran Ali Jarwara, Mehrunisa Sial a}

${ }^{a}$ Department of Agricultural Economics, Sindh Agriculture University Tando Jam, Pakistan

${ }^{b}$ Rural Development and Management Studies, China Agriculture University, Bejing

${ }^{c}$ Agriculture Extension, Agriculture, Supply \& Prices Department Government of Sindh, Pakistan

\section{ARTICLE INFO}

\section{Article history}

Received: October 11, 2020

Accepted: December 28, 2020

Published: December 29, 2020

\section{Keywords}

Climate change

Banana

Cropping pattern

Practices

Sindh

\section{ABSTRACT}

Pakistan is one of the most vulnerable countries in the world due to changing climatic conditions. While a head facing the risk of food and nutrition insecurity. It is a land of variety both in terms of resources and people. The study focused on the district Thatta and its coastal district of Sindh province, to determine the complex problem-related climate change and effects; the district has received due to various climatic factors. Banana is known to be the most important fruit crop of Pakistan. It is cultivated over 34,800 hectares with the production of 154,800 tons. It is primarily grown in Sindh province because the soil and climatic conditions favour cultivating fruits and vegetables, further, this province shares 87 percent in the cultivation of the banana crop. The study aims to carry out the impact of climate change effect on banana cropping patterns. The present study aimed to observe the socio-economic characteristics of the farmers, review the present status of banana production in Sindh province, explore the status of cropping pattern in the study area, and examine climate change effect on banana cropping pattern, by using primary as well as secondary data. In Sindh province, Banana is cultivated in three main districts among them, Thatta shares 17.6 percent in the area and 17.1 percent production in the overall province. Furthermore, farmer's perception regarding climate change, the majority proportion of farmers agreed temperature has raised and cropping pattern practices also effected and changed, while water-related issues are rising day by day in the study area.

* Corresponding Author: Ghulam Nabi Dahri

Email: ghullamnabi064@gmail.com

(C) The Author(s) 2020.

\section{INTRODUCTION}

Banana (Musa acuminata) is the fruit of the genus Musa and belongs to the family of Musaceae, one of the most important horticultural fruit crops of the world. The tropical region is considered as most favorable for the cultivation of the banana crop. It is the main source of vitamin " $\mathrm{C}$ " which adds in the nutritional value (AlDaour et al., 2019), food, and income, while millions of urban and rural people are engaged in this business. According to the statistics locally 80 percent of the fruit is consumed, and 20 percent of total production is found to be exported widely (Jeffery, 2013). Around 5.6 million hectares of the world land is favorable to banana fruit crop globally (FAO, 2017). The banana industry is manifest in 1993 were grown 3.6 million hectares and 4.6 million hectares in 2000 (FAO, 2017). Besides the land allocation, globally the most leading region in Banana production is Asia, which accounts for 50.82\% of total production by following America (32.97\%), Africa (14.09\%), Oceania (1.55\%), and Europe (0.57\%.) It is the most exported fresh fruit of the world, which accounts for US\$10 bn/year. In developing countries, it is the source of income for rural households (FAO, 2017). 
Banana is widely cultivated in 130 countries including the Philippines, Bangladesh, Thailand Indonesia, Vietnam, India, and Pakistan. It has occupied the most important position in the agricultural economy and ranks as a leading crop in world agricultural production and trade (FAO, 2013). The most commercialized variety is Cavendish, which is cultivated about 47 percent among the 1000 verities of Banana. It is mostly consumed in China and India (FAO, 2020). Banana is calculated as a major fruit crop in Pakistan. It is grown on 34,800 hectares with a production of 154,800 tons. Sindh province shares 87 percent, which is a huge amount in banana production (CABI, 2018). While Thatta is considered as the second productive district, which shares 16 percent in Sindh production. The crop has occupied an area of about 10,000 acres (404.686 hectares) in the study area (Alamgir et al., 2015).

Pakistan is one of the most vulnerable countries due to changing climatic conditions. While a head facing the risk of food and nutrition insecurity. It is the land of variety, both in terms of resources and people (WFP, 2018). Climatic conditions are changing day by day due to the high emission of $\mathrm{CO} 2$, It is mostly the arid and semi-arid area about $250 \mathrm{~mm}$ less rainfall occurs every year (Rasul et al., 2012). The risk-taking regions are coastal region and the Indus delta regions like Thatta and Badin. In these regions, it is expected to rise in sea level and excessiveness in soil saline, the most important thing faced is coastal erosion, seawater intrusion, and an increase in cyclone in the Arabian Sea. While the district Thatta is considered as a coastal region that's why drinking water quality is going down. Most health issues are increasing like diarrhea, vector borne disease, and Cholera (Chandio et al., 2018). Climate change may lead to a substantial deterioration in the production of Pakistan. The growth of bananas is blocked up by several climatic factors like temperature, high water demand at every stage. Low and high temperature affect the banana plant and as well as its fruit. High temperature damages the plant while the low temperature can cause damages in fruit, it slows down its growth and quality of fruit. Waterlogging and water shortage sensitize the banana crop. Yield is also affected by numerous pests and diseases (Varun and Daniel, 2020). Keeping in view the above-stated facts, this study was aimed to examine the impact of climate change on Banana based cropping pattern in district Thatta, to observe the socio-economic status of the farmers, to inspect the climate change effect on banana cropping pattern, to reconnoiter the status of cropping pattern in the study area and to assess the present status and banana production in different district of Sindh province.

\section{METHODOLOGY}

The research methodology is the basic theme of the research plan or outline by which research is to be done. A descriptive type of research design is used in the present study. It is suitable for obtaining the respondent's perception about the current condition in the existing nature (Gall and Brog, 1989; Trochim 2000; Gall et al., 2007). The survey is the basic tool of research and commonly used for data collection in the field (Gall et al., 2006). According to Leedy (2005), it provides a strategy and framework for data collection. The map of the study area is shown in Figure 1.

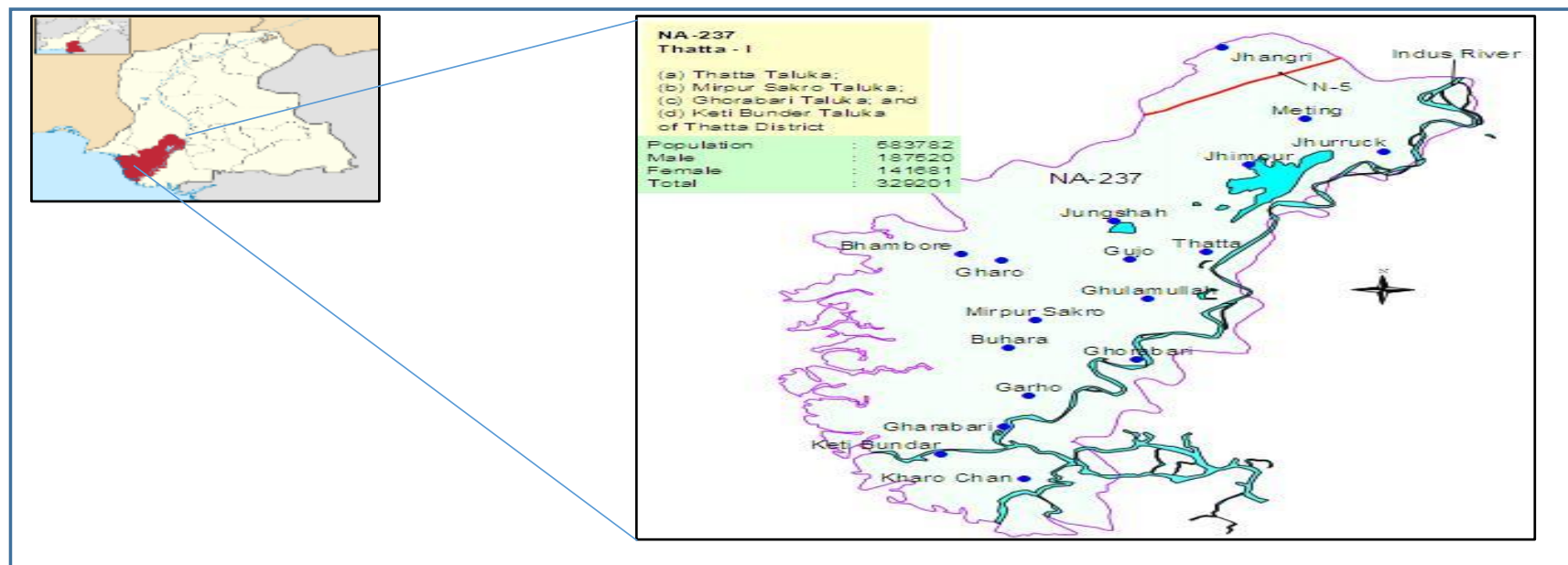

Figure 1. Map of the study area.

Sampling is considered as the crucial issue, through which the researcher clarify, how the data was collected
(Fox et al., 2009). This study was based on primary as well as secondary data, for primary data, the 
questionnaire was developed and pretested in the field while the secondary data were collected from reports, government departments, and different research papers. District Thatta was further divided into four sub-districts or Tehsils namely Thatta, Mirpur Sakro, Keti Bander, Ghorabari. While both data were collected in the shape of quantitative and qualitative according to the impact of climate change effect on banana-based cropping pattern in district Thatta, it is purposely selected district because it is the second productive district of Sindh province in banana production. A comprehensive research instrument was designed by keeping in view, the objectives of the present study.

Data were analyzed by Statistical Package for Social Science (SPSS) and Microsoft Excel; to measure the percentage, average, ratio, and standard deviation. While farmers were divided into two categories small farmers (up to 12.5) and large farmers (12.5 and above).

\section{RESULTS AND DISCUSSION \\ Area and Production of Pakistan}

Banana is the most important fruit crop and grown in all provinces of Pakistan. The Sindh province shares the major portion, which is about 82 percent, Punjab 5 percent, KPK 9.9 percent and Baluchistan shares 3 percent in overall production (Table 1).

\section{Area and Production of Banana in Sindh}

In Sindh province, Banana is mostly grown in Khairpur, Thatta, Matiari, and Shaheed Benazirabd districts. According to the share in production, Khairpur district is at the first number and Thatta is at the second number as shown in Table 2.

Table 1. Provinces wise area and production (“000” Hec).

\begin{tabular}{llllll}
\hline Year & Punjab & Sindh & KPK & Baluchistan & Pakistan \\
\hline (Area “000” hec) & & & & & 27.3 \\
\hline $2014-15$ & 0.7 & 25.0 & 0.7 & 0.9 & 28.0 \\
$2016-17$ & 0.5 & 25.9 & 0.7 & 0.9 & 28.4 \\
$2017-18$ & 1.0 & 25.9 & 0.7 & 0.8 & 100.0 \\
Average area & 3.4 & 91.2 & 2.5 & 2.9 & 141.3 \\
\hline (Production '000' tonnes) & 4.3 & 121.2 & 13.1 & 2.7 & 120.4 \\
\hline 2014-15 & 3.8 & 100.8 & 13.1 & 2.7 & 131.2 \\
$2016-17$ & 6.8 & 107.8 & 13.0 & 3.6 & 100.0 \\
2017-18 & 5.2 & 92.1 & 9.9 & 2.8 &
\end{tabular}

Source: Author and analysis based on GOP data.

Table 2. District wise area and banana production (Hec /tons).

\begin{tabular}{lllll}
\hline Districts & Area & Percent & Production & Percent \\
\hline Khairpur & 5121 & 25.9 & 21563 & 28.4 \\
Ghotki & 203 & 1.0 & 885 & 1.2 \\
Sukkur & 107 & 0.5 & 460 & 0.6 \\
N. Feroze & 1772 & 9.0 & 8022 & 10.5 \\
SBA & 2136 & 10.8 & 8656 & 11.4 \\
Jaccobabad & 0 & 0.0 & 0 & 0.0 \\
Kashmore & 0 & 0.0 & 0 & 0.0 \\
Shikarpur & 8 & 0.0 & 32 & 0.0 \\
Larkana & 0 & 0.0 & 0 & 0.0 \\
Kamber & 0 & 0.0 & 0 & 0.0 \\
Sanghar & 1492 & 7.6 & 0 & 5.4 \\
Tharparkar & 0 & 0.0 & 583 & 0.0 \\
Mirpurkhas & 312 & 1.6 & 130 & 0.8 \\
Umerkot & 65 & 0.3 & 224 & 0.2 \\
Dadu & 65 & 0.3 & 178 & 0.3 \\
Jamshoro & 50 & 0.3 & 1670 & 0.2 \\
Hyderabad & 412 & 2.1 & 10458 & 2.2 \\
Matiari & 2713 & 13.7 & & 13.8
\end{tabular}




\begin{tabular}{|c|c|c|c|c|}
\hline Tando Allahyar & 702 & 3.6 & 2248 & 3.0 \\
\hline T.M.Khan & 537 & 2.7 & 1847 & 2.4 \\
\hline Badin & 412 & 2.1 & 1271 & 1.7 \\
\hline Thatta & 3472 & 17.6 & 13041 & 17.1 \\
\hline Karachi & 177 & 0.9 & 630 & 0.8 \\
\hline Total & 19756 & 100.0 & 76042 & 100.0 \\
\hline
\end{tabular}

Source: Authors analysis based on GOP data.

Socio-economic Characteristics of Banana Growers

Socioeconomic characteristics play an important role in every society. Education is known to be a building bridge of society. While individual decision making power determines the education and experience of an individual.

\section{Age, Education, and Farming Experience}

The average age was 46 year and education was up to 7 years, it means education level was very low in the study area. Education is very important for awareness, while the farming experience was good in the study area (Table 3).

\section{Land Holding}

Landholding size in the study area was small farmers having land size was 6 acre and large farmers having land size was 26 acre. While small farmers having more noncultivated area as compared to the large farmers. Low income was the major factor seen in small farmers. Most of the farmers were not able to afford the purchasing power of input that's why they preferred to leave the fellow land. Operational landholding of small farmers was 9 acres and large farmers had 33 acres in the study area. The distribution of respondents according to the size of landholding is shown in Table 4.

Table 3. Age, education and farming experience of the respondents.

\begin{tabular}{lcccc}
\hline \multirow{2}{*}{ Farm category } & \multicolumn{2}{c}{ Small } & \multicolumn{2}{c}{ Large } \\
\cline { 2 - 5 } & Mean & S. D & Mean & S. D \\
\hline Age (year) & 46.3 & 13.0 & 39.4 & 13.2 \\
Education & 7.2 & 4.8 & 6.8 & 5.7 \\
Farming experience & 14.4 & 8.7 & 12.6 & 10.1 \\
\hline
\end{tabular}

Table 4. Land holding size in study area.

\begin{tabular}{lcccc}
\hline \multirow{2}{*}{ Farm category } & \multicolumn{2}{c}{ Small } & \multicolumn{2}{c}{ Large } \\
\cline { 2 - 5 } & Mean & S. D & Mean & S. D \\
\hline Cultivated & 5.9 & 2.5 & 26.6 & 21.5 \\
Non-cultivated & 1.3 & 1.2 & 2.0 & 5.1 \\
Operational holding & 8.8 & 3.4 & 33.2 & 23.3 \\
\hline
\end{tabular}

Table 5. Different sources of household income (percent).

\begin{tabular}{|c|c|c|c|c|c|}
\hline \multicolumn{2}{|c|}{ Farm category } & Banana & Intercropping & Livestock & Off-farm \\
\hline \multirow{2}{*}{ Small } & Mean & 40.19 & 21.48 & 3.04 & 20.48 \\
\hline & Std. deviation & 30.33 & 19.94 & 5.02 & 27.23 \\
\hline \multirow{2}{*}{ Large } & Mean & 28.32 & 16.79 & 5.64 & 11.39 \\
\hline & Std. deviation & 26.44 & 20.09 & 9.98 & 17.75 \\
\hline
\end{tabular}

\section{Income of Household}

Different sources of income are compared between small and large farmers. Small farmer's income was 40 percent from the banana crop, 21 percent from intercropping, 3 percent from livestock, and 20 percent from off-farm earnings including labour work of the small farmers. While large farmer's income from banana crops was 26 percent, 20 percent from intercropping, 10 percent from livestock, and 18 percent from the off-farm income of large farmers (Table 5).

\section{Perception Regarding Climate Change}

Climate change is considered as a global issue rather than an issue of only Pakistan. Many developing as well as developed nations are affected by climate change. It has affected agricultural production and practices as well. This time is crucial to work for reducing $\mathrm{CO} 2$ carbon emission gases and develop the potential plan for climate 
change. The result of the farmer's perception regarding climate change shows that 86 percent of farmers agreed that temperature had raised. The majority of farmers (64 $\%$ ) believe that climate change has affected agricultural practices and 42 percent of farmers believe that low productivity had occurred due to the impact of climate change. Furthermore, 86 percent of farmers said that the water scarcity problem was increasing day by day, while a majority of farmers don't know about soil fertility. The results of farmer's perceptions regarding the impact of climate change are shown in Table 6.

Climate change is a worldwide issue faced by everyone. The data were collected regarding the perception of farmers about the impact of climate change by asking questions related to climate change. Most of the farmers said that climate change has affected every aspect of life, most of the farmers believe that the rise in temperature affected banana production and cropping practices as well, cropping pattern seem to be the most important issue in the study area, most of the farmers agreed that crop productivity has been reduced continuously due to different climatic factors, soil fertility also effected but most of the farmers don't know about it. Results state that climate change has been affecting every people in every aspect of life.

Table 6. Farmer's perception regarding the climate change (percent).

\begin{tabular}{llll}
\hline Perception & Agree & Disagree & Don't Know \\
\hline Temperature has raised & 86 & 9 & 3 \\
Climate change effect cropping practices & 64 & 25 & 11 \\
Crop productivity reduce & 42 & 34 & 24 \\
Water related issues raised & 86 & 9 & 5 \\
Soil fertility reduced & 34 & 22 & 44 \\
\hline
\end{tabular}

Table 7. Rabi cropping pattern.

\begin{tabular}{lcccc}
\hline \multirow{2}{*}{ Farm category/ Characteristics } & \multicolumn{2}{c}{ Small } & \multicolumn{2}{c}{ Large } \\
\cline { 2 - 5 } & Mean & Operation \% & Mean & Operation \% \\
\hline Wheat & 1.1 & 25.3 & 15.2 & 49.3 \\
Fodder & 0.1 & 2.5 & 0.4 & 1.3 \\
Sugarcane & 0.3 & 5.7 & 0.8 & 2.8 \\
Lemon & 0.0 & 0.0 & 0.3 & 0.9 \\
Vegetables & 0.0 & 0.7 & 0.6 & 2.2 \\
Fallow & 0.2 & 3.3 & 7.9 & 0.6 \\
Banana orchard & 2.8 & 53.4 & 2.2 & 27.1 \\
Dates orchard & 0.3 & 6.6 & 1.1 & 7.7 \\
Mango orchard & 0.3 & 5.4 & 29.0 & 3.9 \\
Operational & 5.2 & 100.0 & & 100.0 \\
\hline
\end{tabular}

Table 8. Cropping pattern in kharif season.

\begin{tabular}{lcccc}
\hline \multirow{2}{*}{ Farm Categories/ Characteristics } & \multicolumn{3}{c}{ Small } & \multicolumn{3}{c}{ Large } \\
\cline { 2 - 5 } & Mean & Operation \% & Mean & Operation \% \\
\hline Rice & 0.3 & 5.8 & 1.6 & 5.5 \\
Fodder & 0.3 & 5 & 0.6 & 2.2 \\
Cotton & 0.6 & 11.5 & 8.1 & 27.9 \\
Vegetables & 0.1 & 1.4 & 0.5 & 1.7 \\
Other crops & 0 & 0 & 4.7 & 10.2 \\
Sugarcane & 0.3 & 5.5 & 0.8 & 4.1 \\
Lemon & 0.3 & 5.7 & 0.3 & 2.8 \\
Dates orchard & 0 & 0 & 7.9 & 0.9 \\
Banana orchard & 2.8 & 55.4 & 2.2 & 33.1 \\
Mango orchard & 0.3 & 4.6 & 1.1 & 7.7 \\
Fallow area & 0.3 & 5.4 & 29 & 3.9 \\
Operational & 5.2 & 100 & 100
\end{tabular}




\section{Cropping Pattern in Rabi Season}

In the Rabi season cropping pattern of small and, large farmers are compared according to different crops. Small farmers have cultivated 25 percent wheat and large farmers 49 percent. The majority of small farmers focus on orchard crops as banana cultivation. Small farmers preferred to cultivate 53 percent banana crop and large farmer 27 percent. The third major fruit crop was mango orchard cultivation in the study area in the Rabi season as shown the given Table 7.

\section{Cropping Pattern in Kharif Season}

In the Kharif season majority of small farmers preferred to cultivate the banana crop, which is 55 percent, while large farmers cultivated 33 percent. The second cultivated crop among the large farmers was the cotton crop which is 28 percent and the small farmer cultivated 11 percent. Large farmers preferred to cultivate cotton crops as compare to small farmers (Table 8).

\section{CONCLUSIONS}

This study was aimed to examine the impact of climate change on banana based cropping pattern in district Thatta. Climate change is a global issue faced by everyone in every aspect of life. Pakistan is listed among the most vulnerable countries. The climatic factors influenced a lot of agricultural productivity; specifically banana production. It also threatened nutrition and food security. Banana is known to be the most important fruit crop of Pakistan. It is cultivated over 34,800 hectares with the production of 154,800 tons. It is primarily grown in Sindh province because the soil and climatic conditions favor cultivating fruits and vegetables, further, this province shares 87 percent in the cultivation of the banana crop. There are three main districts that contribute to Sindh production. Among them, Thatta's share is $\mathbf{1 7 . 6}$ percent. Crop productivity is reducing day by day due to the adverse effect of climate change in the study area. Banana growth is challenged at every stage due to excessive rainfall, fluctuation of temperature, low quality of groundwater, and reducing soil fertility. Low and hightemperature affected the banana plant and as well as its fruit. High temperature damages the plant while the low temperature can cause damages to fruit. Climate change has a severe impact on its growth and quality of fruit. Waterlogging and water shortage sensitize the banana crop. Yield is also affected by numerous pests and diseases.

\section{REFERENCES}

Alamgir A., Khan, M.A., Shoukat, S.S., Burfat, F.M., Mehmood, K., 2015. Impact of climate change on the socioeconomic conditions: A case study of district Thatta, Sindh, Pakistan. Bulletin of Environment, Pharmacology and Life Sciences, 4(6), 93-10.

Al-Daour A.F., Al-shawwa, M.O.., Abu-Naser, S.S., 2019. Banana classification using deep learning. International Journal of Academic Information Systems Research, 3(12), 6-11.

CABI, 2018. Survey report on technological \& social constraints of banana production in Sindh, Pakistan. Centre for Agricultural and Biosciences International.

Chandio, N.H., Anwar, M.M., Mallah, Q.H., 2018. Impacts of climate change on coast line of Arabian Sea: A case study of Indus River Delta, Pakistan. Sindh Univ. Res. Jour., 50 (1), 147-152.

FAO, 2013. Banana market- review and banana statistics, 2012-13, FAO Faostat Database, United Nation.

FAO, 2017. Food and Agriculture Organization, World jbanana forum, http://www.fao.org/world-bananaforum/about-the-forum/en/.

FAO, 2020. Food and Agriculture Organization, Banana facts and figures. Retrieved from the website.

http://www.fao.org/economic/est/estcommodi ties/bananas/bananafacts/en/\#.XzjAyugzbIU/.

Fox, N., Hunn, A., Mathers, N., 2009. Sampling and sample size calculation. Retrieved from https://www.bdct.nhs.uk/wpcontent/uploads/2019/04/Sampling-and-SampleSize-Calculation.pdf.

Gall, M.D. and Borg, W.R., 1989. Educational research. A guide for preparing a thesis or dissertation proposal in education. Longman, Inc., Order Dept., 95 Church Street, White Plains, NY 10601 Stock No. 78164-6.

Gall, M.D., Gall, J.P., Borg, W.R., 2006. Educational research: An introduction (6th Ed.). USA: Longman.

Gall, M.D., Gall, J.P., Borg, W.R., 2007. Educational research: An introduction (8th Ed.). USA: Longman.

Jeffery, M., 2013. Banana - Their history, cultivation and production (Facts and figures details.com). Ministry of National Food Security and Research, Islamabad. Pakistan.

Leedy, P.D., 2005. Practical research. Prentice-Hall Career \& Technology, USA. p. 77.

Rasul, G., Mehmood, A., Sadiq, A., Khan, S.I., 2012. Vulnerability of the Indus Delta to climate change in Pakistan. Pakistan Journal of Meteorology, 8(16), 89-108. 
Trochim, W., 2000. The research methods knowledge base, 2nd Edn Cincinnati. OH: Atomic Dog Publishing.

Varun, V., Daniel, P.B., 2020. Climate change impacts on banana yields around the world. 2019 Oct; 9(10): 752-757. 10.1038/s41558-019-0559-9.
WFP, 2018. Climate risks and food security analysis: A special report for Pakistan. Retrieved from the web page: https://reliefweb.int/sites/reliefweb.int/files /resources/Climate_Risks_and_Food_Security _Analysis_December_2018.pdf.

Publisher's note: Science Impact Publishers remain neutral with regard to jurisdictional claims in published maps and institutional affiliations.

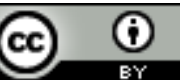

Open Access This article is licensed under a Creative Commons Attribution 4.0 International License, which permits use, sharing, adaptation, distribution and reproduction in any medium or format, as long as you give appropriate credit to the original author(s) and the source, provide a link to the Creative Commons license and indicate if changes were made. The images or other third-party material in this article are included in the article's Creative Commons license, unless indicated otherwise in a credit line to the material. If material is not included in the article's Creative Commons license and your intended use is not permitted by statutory regulation or exceeds the permitted use, you will need to obtain permission directly from the copyright holder. To view a copy of this license, visit https://creativecommons.org/licenses/by/4.0/.

(C) The Author(s) 2020 